\title{
Proximal motor neuropathy, IgA paraproteinaemia and anti-myelin-associated glycoprotein reactivity
}

\author{
Thiravat Hemachudha, Praphan Phanuphak, Kammant Phanthumchinda and \\ Songsri Kasempimolporn
}

\author{
Neurology and Immunology Division, Department of Medicine, Chulalongkorn University Hospital, and Science \\ Division, Queen Saovabha Memorial Institute, Bangkok, Thailand.
}

\begin{abstract}
Summary: We report a case with proximal motor neuropathy associated with benign IgA lambda paraproteinaemia. Immunoblot demonstrated reactivity to myelin-associated glycoprotein and not to $\mathbf{P}_{2}$ protein of peripheral nerve. Dramatic improvement of the polyneuropathy was observed with steroid treatment alone within 4 weeks.
\end{abstract}

\section{Introduction}

Peripheral neuropathy in association with monoclonal gammopathy, especially that of IgM, has been increasingly recognized since the reports of Latov $^{1}$ and Braun. ${ }^{2}$ The most prevalent IgM antibody activity is directed against myelin-associated glycoprotein (MAG). ${ }^{2,3}$ Other target antigens, such as glycolipids, gangliosides and chrondroitin sulphate have also been defined. ${ }^{4-7}$ Immuno-suppressive therapy directed at lowering the anti-MAG M-protein concentration did not always result in improvement of the neuropathy. ${ }^{8-11}$ Plasmapheresis in these patients may be beneficial when performed on a weekly basis for prolonged periods. ${ }^{12}$

We report a patient with proximal motor neuropathy with benign IgA lambda paraproteinaemia and MAG reactivity. Dramatic clinical improvement was observed with steroid treatment alone.

\section{Case report}

A 69 year old Thai monk presented with a 2-month history of progressive weakness of both arms and legs which worsened so that he became chairbound prior to admission. He denied symptoms of numbness or difficulty in urination. There was no history of hexacarbon abuse, glue sniffing, porphyria, diphtheria, or lead exposure.

Correspondence: Thiravat Hemachudha, M.D., Neurology Division, Department of Medicine, Chulalongkorn University Hospital, Rama IV Road, Bangkok 10500, Thailand.

Accepted: 10 March 1989
On examination, he was alert and coherent. There was generalized weakness of the axial and limb musculature with no wasting or fasciculations. Weakness was most severe in muscles of the shoulder girdle, upper arms, and pelvic girdle (III/V, MRC) with relative sparing of distal muscles (IV/V). Deep tendon reflexes were absent. The plantar responses were flexor, and results of the sensory examination were normal including joint position and vibratory sense. Results of the general examination were normal. There was no lymphadenopathy or hepato splenomegaly.

Laboratory data revealed a haemoglobin of $11.9 \mathrm{~g} / \mathrm{dl}$, packed cell volume of $36 \%$ and leucocyte count of $6.5 \times 10^{9} / 1$. Other laboratory tests included normal fasting plasma glucose, creatinine, electrolytes, and liver function tests. Serum protein electrophoresis showed a monoclonal band (M-spike) at the betaglobulin region. This was characterized as IgA lambda by immunoelectrophoresis and also confirmed by immunofixation. The level of $\operatorname{IgA}$ was $0.87 \mathrm{~g} / \mathrm{dl}$ (normal: $0.316 \pm 0.129$ ). The IgG and IgM levels were within normal range. Urine Bence Jones protein was not detected nor was serum cryoglobulin. A bone marrow aspirate revealed $4 \%$ plasma cells. A skeletal survey showed no osteolytic or sclerotic lesions. The level of cerebrospinal fluid (CSF) protein was $1.1 \mathrm{~g} / 1$ and there were no cells in the CSF. Nerve conduction studies revealed a reduction of motor-nerve-conduction velocities of the median nerve $(32 \mathrm{~m} / \mathrm{s})$ and of the common peroneal nerve $(30 \mathrm{~m} / \mathrm{s}$ ) (normal value, above 46 and $40 \mathrm{~m} / \mathrm{s}$ for median and common peroneal nerve respectively). A sural nerve biopsy specimen showed segmental demyelination.

(C) The Fellowship of Postgraduate Medicine, 1989 
Serum was assayed for the presence of antibody against MAG, and $P_{2}$ protein by immunoblot as previously described. ${ }^{13,14}$ Banked serum from 5 patients with other neurological diseases including sporadic Guillain-Barré syndrome (GBS), thiamine polyneuropathy and Semple vaccination-induced polyneuritis served as controls. Antibody to MAG, not to $P_{2}$ protein, could be demonstrated in serum of this patient. Five control patients had no antibody to MAG or $P_{2}$ protein.

Therapy with prednisolone $60 \mathrm{mg} /$ day resulted in dramatic clinical improvement. After one month, he could walk a distance of 15 metres without support and climbed stairs with the aid of a railing. On examination, muscle strength had improved by one grade in the proximal muscles. Two months after starting prednisolone, muscle strength returned to normal. There was no limitation in functional activity. Deep tendon reflexes, however, were still absent. Clinical improvement coincided with a decrease in the IgA level which fell to $0.67 \mathrm{~g} / \mathrm{dl}$ and the $M$ band declined to an undetectable level. Improvement was also confirmed by motor-nerve-conduction velocities of median and common peroneal nerves which rose to $40 \mathrm{~m} / \mathrm{s}$. Four months after initiation of treatment with prednisolone, at which time the dosage was tapered to $20 \mathrm{mg}$ daily, there was a subjective deterioration in strength. A further skeletal survey showed no changes.

\section{Discussion}

Monoclonal gammopathy is reported in $10 \%$ of patients with polyneuropathy. ${ }^{15}$ Particular attention

\section{References}

1. Latov, N., Braun, P.E., Gross, R.B., Sherman, W.H., Penn, A.S. \& Chess, L. Plasma cell dyscrasia and peripheral neuropathy: identification of the myelin antigens that react with the human paraproteins. Proc Natl Acad Sci USA 1981, 78: 7139-7142.

2. Braun, P.E., Frail, D. \& Latov, N. MAG is the antigen for a monoclonal antibody in patients with a demyelinating neuropathy. $J$ Neurochem 1982, 39: 1261 - 1265.

3. Steck, A.J., Murray, N., Meier, C. et al. Demyelinating neuropathy and monoclonal IgM antibody to myelin associated glycoprotein. Neurology 1983, 33: 19-23.

4. Ilyas, A.A., Quarles, R.H., Dalakas, M.C. \& Brady, R.O. Polyneuropathy with monoclonal gammopathy: glycolipids are frequently antigens for IgM paraproteins. Proc Natl Acad Sci USA 1985, 82: 6697-6700.

5. Ilyas, A.A., Quarles, R.H., Dalakas, M.C. et al. Monoclonal IgM in a patient with paraproteinaemic polyneuropathy binds to gangliosides containing disialosyl groups. Ann Neurol 1985, 18: 655-659. has been focused on IgM M-protein due to its more common prevalence and its specificity to unique antigen such as MAG. ${ }^{8,16-18}$ There seem to be no reports of neuropathy with MAG reactivity and immunoglobulins other than IgM proteins. ${ }^{8,10}$ Generally, anti-MAG reactivity indicates an unsatisfactory response to apheresis, chemotherapy, or steroids in patients with IgM monoclonal gammopathy ${ }^{8-10,17}$

The patient described herein had benign $\operatorname{IgA}$ lambda monoclonal gammopathy with reactivity to MAG. Immune responses to $P_{2}$ protein had been detected in some studies of patients with sporadic GBS $^{19-22}$ but not in all ${ }^{14,23}$ and have not been reported in patients with neuropathy and paraproteinaemia. Failure to detect antibody to $\mathrm{P}_{2}$ protein confirmed, unique specificity of this entity. The clinical pattern of proximal demyelinating motor neuropathy was somewhat atypical, since neuropathies found in association with paraproteinaemias, with or without MAG reactivity, are usually distal sensorimotor or pure sensory neuropathies. ${ }^{8-10,16,17,24} \mathrm{~A}$ case of proximal motor neuropathy, dermato-endocrine syndrome associated with IgG kappa paraproteinaemia has been reported. ${ }^{25}$ However, it was not known whether these antibodies reacted against MAG. Good response to steroid treatment was another atypical feature. This patient, without any adjunct chemotherapy or plasmapheresis, improved with the use of steroids alone and his clinical status was still maintained with only low dose. We feel that MAG reactivity alone may not be a poor indicator for treatment outcome in polyneuropathy associated with paraproteinaemia.

6. Freddo, L., Yu, R.K., Latov, N. et al. Gangliosides GM $_{1}$ and $G_{1} b$ are antigens for IgM M-protein in a patient with motor neuron disease. Neurology 1986, 36: 454-458.

7. Sherman, W.H., Latov, N., Hays, A.P. \& Takatsu, M. Monoclonal IgM antibody precipitating with chondroitin sulphate $\mathrm{C}$ from patients with axonal polyneuropathy and epidermolysis. Neurology 1983, 33: 192-201.

8. Hafler, D.A., Johnson, D., Kelly, J.J., Panitch, H., Kyle, R. \& Weiner, H.L. Monoclonal gammopathy and neuropathy: myelin-associated glycoprotein reactivity and clinical characteristics. Neurology 1986, 36: 75-78.

9. Nobile-Orazio, E., Baldini, L., Barbieri, S. et al. Treatment of patients with neuropathy and anti-MAG IgM M-proteins. Ann Neurol 1988, 24: 93-97. 
10. Melmed, C., Frail, D., Duncan, I. et al. Peripheral neuropathy with IgM kappa monoclonal immunoglobulin directed against myelin-associated glycoprotein. Neurology 1983, 33: 1397-1405.

11. Sherman, W.H., Olarte, M.R., McKiernan, G. et al. Plasma exchange treatment of peripheral neuropathy associated with plasma cell dyscrasia. $J$ Neurol Neurosurg Psychiatry 1984, 47: 813-819.

12. Haas, D.C. \& Tatum, A.H. Plasmapheresis alleviates neuropathy accompanying IgM anti-myelin-associated glycoprotein paraproteinaemia Ann Neurol 1988, 23: 394-396.

13. Hemachudha, T., Griffin, D.E., Giffels, J.J., Johnson, R.T., Moser, A.B. \& Phanuphak, P. Myelin basic protein as an encephalitogen in encephalomyelitis and polyneuritis following rabies vaccination. N Engl J Med 1987 , 316: $369-374$.

14. Hemachudha, T., Griffin, D.E., Chen, W.W. \& Johnson, R.T. Immunologic studies of rabies vaccination-induced Guillain-Barré syndrome. Neurology 1988, 38: 375-378.

15. Kelly, J.J. Jr., Kyle, R.A., O'Brien, P.C. et al. Prevalence of monoclonal protein in peripheral neuropathy. Neuro$\log y$ 1981, 31: 1480-1483.

16. Dalakas, M.C. \& King Engel, W. Polyneuropathy with monoclonal gammopathy: studies of 11 patients. Ann Neurol 1981, 10: 45-52.

17. Nobile-Orazio, E., Marmiroli, P., Baldini, L. et al. Peripheral neuropathy in macroglobulinemia: incidence and antigen-specificity of M proteins. Neurology 1987, 37: $1506-1514$.

18. Steck, A.J., Murray, N., Dellagi, K., Brouer, J.C. \& Seligmann, M. Peripheral neuropathy associated with monoclonal IgM auto-antibody. Ann Neurol 1987, 22: $764-767$.
19. Geezy, C., Raper, F., Roberts, I.M., Meyer, P. \& Bernard, C.C.A. Macrophage procoagulant activity as a measure of cell mediated immunity to $P_{2}$ protein of peripheral nerves in the Guillain-Barré syndrome. $J$ Neuroimmunol 1985, 9: 179-191.

20. Luijten, J.A.F.M., De Jong, W.A.C., Demel, R.A., Heijnen, C.J. \& Ballieux, R.E. Peripheral nerve $\mathbf{P}_{2}$ basic protein and the Guillain-Barré syndrome: in vitro demonstration of $\mathrm{P}_{2}$ specific antibody secreting cells. $J$ Neurol Sci 1984, 66: 209-216.

21. Abramsky, O., Korn-Lubetzky, I. \& Teitelbaum, D. Association of autoimmune diseases and cellular immune response to the neuritogenic protein in GuillainBarré syndrome. Ann Neurol 1980, 1: 117.

22. Sheremata, W., Colby, S., Karkhamis, Y. \& Eylar, E.H. Cellular hyper-sensitivity to basic myelin $\left(\mathbf{P}_{2}\right)$ protein in the Guillain-Barré syndrome. Can J Neurol Sci 1975, 2: 87-90.

23. Zweiman, B., Rostami, A., Lisak, R.P., Moskovitz, A.R. \& Pleasure, D.E. Immune reactions to $P_{2}$ protein in human inflammatory demyelinative neuropathies. Neurology 1983, 33: 234-237.

24. Kelly, J.J., Kyle, R.A., Miles, J.M. et al. Osteosclerotic myeloma and peripheral neuropathy. Neurology 1983, 33: $202-210$.

25. Berkovic, S.F., Scarlett, J.D., Symington, G.R., Dennett, X. \& Woodruff, R.K. Proximal motor neuropathy, dermato-endocrine syndrome, and IgGk paraproteinemia. Arch Neurol 1986, 43: 845-848. 